Original Article

\title{
Plant metabolite 5-pentadecyl resorcinol is produced by the Amazonian fungus Penicillium sclerotiorum LM 5679
}

\author{
O metabólito vegetal 5-pentadecil resorcinol é produzido pelo fungo amazônico \\ Penicillium sclerotiorum LM 5679
}

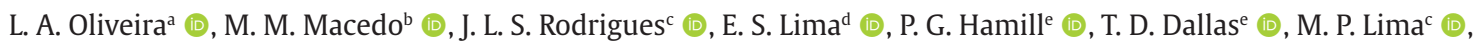 \\ E. S. Souza ${ }^{a}$ J. E. Hallsworthe (D) and J. V. B. Souza ${ }^{\text {f* }}$ (1) \\ anniversidade do Estado do Amazonas - UEA, Manaus, AM, Brasil

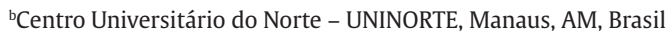 \\ 'Instituto Nacional de Pesquisas da Amazônia - INPA, Departamento de Produtos Naturais, Manaus, AM, Brasil \\ dUniversidade Federal do Amazonas - UFAM, Manaus, AM, Brasil \\ 'Queen's University Belfast, Institute for Global Food Security, School of Biological Sciences, Belfast, UK \\ fInstituto Nacional de Pesquisas da Amazônia - INPA, Laboratório de Micologia, Manaus, AM, Brasil
}

\begin{abstract}
Since the classic studies of Alexander Flemming, Penicillium strains have been known as a rich source of antimicrobial substances. Recent studies have identified novel metabolites produced by Penicillium sclerotiorum that have antibacterial, antifouling and pharmaceutical activities. Here, we report the isolation of a P. sclerotiorum (LM 5679) from Amazonian soil and carry out a culture-based study to determine whether it can produce any novel secondary metabolite(s) that are not thus-far reported for this genus. Using a submerged culture system, secondary metabolites were recovered by solvent extract followed by thin-layer chromatography, nuclear magnetic resonance, and mass spectroscopy. One novel secondary metabolite was isolated from P. sclerotiorum (LM 5679); the phenolic compound 5-pentadecyl resorcinol widely known as an antifungal, that is produced by diverse plant species. This metabolite was not reported previously in any Penicillium species and was only found once before in fungi (that time, in a Fusarium). Here, we discuss the known activities of 5-pentadecyl resorcinol in the context of its mode-of-action as a hydrophobic (chaotropicity-mediated) stressor.
\end{abstract}

Keywords: antifungal compounds, 5-pentadecyl resorcinol or cardol or adispostatin, bioprospecting ascomycete fungi, Penicillium sclerotiorum, secondary metabolites, tropical forest soil.

\section{Resumo}

Desde os estudos clássicos de Alexander Flemming, as cepas de Penicillium são conhecidas como uma fonte rica em substâncias antimicrobianas. Estudos recentes identificaram novos metabólitos produzidos pela espécie Penicillium sclerotiorum com atividades antibacteriana, anti-incrustante e farmacêutica. Aqui, relatamos o isolamento de uma colônia de P. sclerotiorum (LM 5679) do solo amazônico e relatamos também o estudo baseado em cultura para determinar se ele pode produzir qualquer novo metabólito (s) secundário (s) que não foram relatados até agora para este gênero. Usando um sistema de cultura submerso, os metabólitos secundários foram recuperados por extrato de solvente seguido por cromatografia em camada delgada, ressonância magnética nuclear e espectroscopia de massa. Um novo metabólito secundário foi isolado de P. sclerotiorum (LM 5679); o composto fenólico 5-pentadecil resorcinol que é amplamente conhecido como um antifúngico que é produzido por diversas espécies de plantas. Este metabólito não foi relatado anteriormente em nenhuma espécie de Penicillium, e foi encontrado apenas uma vez em fungos (Fusarium). Aqui, discutimos as atividades conhecidas do 5-pentadecil resorcinol no contexto de seu modo de ação como um estressor hidrofóbico (mediado pela caotropicidade).

Palavras-chave: compostos antifúngicos, 5-pentadecil resorcinol ou cardol ou adispostatina, bioprospecção de fungo ascomiceto, Penicillium sclerotiorum, metabólitos secundários, solo de floresta tropical.

\section{Introduction}

Penicillium species, of which there are more than 350, are found in diverse ecosystems ranging from marine habitats to bioaerosols. Their ecology is complex; individual
Penicillium strains can gain sustenance as opportunistic pathogens and saprophytes, and can also have commensal relationships with higher organisms (Park et al., 2019;

*e-mail: joao.souza@inpa.gov.br

Received: August 4, 2020 - Accepted: December 2, 2020 
Hao et al., 2020). Penicillium species are well-known for their ability to compete effectively against other microbes and, since the discovery of penicillin (Fleming, 1929), have been recognized as a rich source of antimicrobials and other secondary metabolites (Kozlovsky et al., 2020).

Recent studies have revealed that $P$. sclerotiorum, isolated from marine habitats, is a rich source of novel secondary metabolites that have antibacterial, trypanocidal, and pharmaceutical activities, and can be used as dyes and as antifouling agents against molluscs (Notarte et al., 2018; Wang et al., 2018; Xin et al., 2019). Soils are key habitats of Penicillium species, where they are known for their ecological versatility, including their various trophic interactions (Bitas et al., 2013; Ceci et al., 2018; Toju and Sato, 2018). Here, we isolate a P. sclerotiorum (LM 5679) from the humic topsoil of a biodiverse ecosystem, the Amazonian rainforest, and carry out a culture-based study to determine whether it can produce any secondary metabolite(s) hitherto unidentified in the Penicillium genus.

\section{Materials and Methods}

\subsection{Sampling and isolation of fungi}

Twenty samples of humic topsoil ( $5 \mathrm{~g}$ each) were collected beneath the forest canopy, at a depth of $5 \mathrm{~cm}$, within the Reserva Florestal Adolpho Ducke, Manaus, Amazonas, Brazil (Latitude: $02^{\circ} 95^{\prime} 43^{\prime \prime} \mathrm{N}$; Longitude: $59^{\circ} 93^{\prime} 39^{\prime \prime} W$. These samples were collected with clean and sterile polythene bags using a sterile spatula. From each collected sample, $1 \mathrm{~g}$ soil was transferred to a tube containing $9 \mathrm{~mL}$ of sterile distilled water; tubes were then shaken for 5 minutes in a vortex mixer (Model K45-2810, Kasvi Paraná-Brazil). From each tube, four successive dilutions were made from $10^{-2}$ to $10^{-5}$ and $0.1 \mathrm{~mL}$ of each suspension was inoculated into Petri dishes containing potato dextrose agar (PDA) (agar, $15 \mathrm{~g} / \mathrm{L}$, dextrose, $20 \mathrm{~g} / \mathrm{L}$ and potato extract, $4 \mathrm{~g} / \mathrm{L}$ ) and then spread over the surface using a sterile Drigalski's spatula (Clark, 1965).

Plates were incubated at $28{ }^{\circ} \mathrm{C}$ for between 24 to 120 hours and then used to inoculate tubes containing PDA using a hook for transferring a small section of the developed fungal culture to tubes containing PDA. Individual fungal strains were isolated by plating individually onto fresh PDA and incubating at $28{ }^{\circ} \mathrm{C}$ for 7 days. Each strain was identified to the genus level by assessing the morphological characteristics using microscopic description of conidia, phialides, metule, conidiophore and hyphae (Riddell, 1950). All fungal strains were deposited into the Microorganism Collection of National Institute for Amazon Research (Manaus, Brazil).

Among the fungi that were isolated, one of the isolates exhibited morphology and pigment production characteristic of $P$. sclerotiorum. We selected this isolate to be investigated for its taxonomy and the production of metabolites due to the biotechnological potential of this species. This selected isolate was investigated by sequencing rDNA ITS region. For this purpose, DNA was extracted from mycelium the phenol:chloroform:isoamyl-alcohol method according to Ferrer et al. (2001). The ITS was amplified using the primers ITS1 (5'-TCCGTAGGTGAACCTGCGG-3') and ITS4 (5'-TCCTCCGCTTATTGATATGC-3') (White et al., 1990) and polymerase chain reaction (PCR) performed using the reagents in the following proportions: $22.5 \mu \mathrm{L}$ of buffer (1X), $5 \mu \mathrm{L}$ of $\mathrm{MgCl}_{2}(2.5 \mathrm{mM}), 2 \mu \mathrm{L}$ of DNTPs $(200 \mu \mathrm{M}), 5 \mu \mathrm{L}$ of each primer $(1.0 \mu \mathrm{M}), 0,5 \mu \mathrm{L}$ of Taq DNA polymerase (1.5 U), $5 \mu \mathrm{L}$ DNA sample (20 ng) and a sufficient amount of ultra-pure water (Direct-Q® 3 UV Water Purification System - Merck Millipore, Burlington, Massachusetts, USA) to a final volume of $30 \mu \mathrm{L}$. The reaction was carried out in the thermocycler SuperCycler ${ }^{\mathrm{TM}}$ SC-200 (Kyratec Pty Ltd, Australia) at the following amplification temperatures: $94{ }^{\circ} \mathrm{C} / 5 \mathrm{~min}, 30$ cycles of $94{ }^{\circ} \mathrm{C} / 30 \mathrm{~s}, 53{ }^{\circ} \mathrm{C} / 30 \mathrm{~s}, 72{ }^{\circ} \mathrm{C} / 1$ min and $72{ }^{\circ} \mathrm{C} / 10 \mathrm{~min}$. PCR products were visualized by UV light after electrophoresis (40 min/100 V/100 A) on agarose gel ( $1.5 \% \mathrm{w} / \mathrm{v}$ agarose, $1.0 \mathrm{M}$ Tris, $0.9 \mathrm{M}$ boric acid, 0.01 M EDTA - TBE buffer), using $2 \mu \mathrm{L}$ of Orange 6X (Fermentas Life Sciences, Massachusetts, EUA) as the sample dye and $6 \mu \mathrm{L}$ of SYBR ${ }^{\circ}$ Safe (Invitrogen by Thermo Fisher Scientific, Califórnia, EUA) as a gel dye. PCR products were purified by precipitation with polyethylene glycol 8000 (PEG 8000) (20\% w/v PEG, $2.5 \mathrm{M} \mathrm{NaCl}$ ). The sequencing reaction was performed with the kit BigDye ${ }^{\circledR}$ (Applied Biosystem, Califórnia, USA) and sequencing was carried out in the Applied Biosystems 3130 Genetic Analyzer (Applied Biosystems, California, USA). The sequences obtained were analyzed using the Basic Local Alignment Search Tool (BLAST®).

\subsection{Fungal cultivation for secondary metabolite production}

A spore suspension of isolate LM 5679 was prepared by adding sterile distilled water $(5 \mathrm{~mL})$ to a sporulated culture (120-hours-old; on 5-mL PDA on slants in 30-L tubes). The spores were dislodged using a sterile inoculation loop under the aseptic conditions and the number of spores was determined using a hemocytometer (Neubauer, Germany) under a light microscope. The volume of $1 \mathrm{~mL}$ of spore suspension containing $1 \times 10^{4}$ spores was used for inoculations.

Erlenmeyer flasks (125 mL) containing 50 mL CzapekDox broth $(3.0 \mathrm{~g} / \mathrm{L}$ sodium nitrate, $1.3 \mathrm{~g} / \mathrm{L}$ potassium phosphate, $0.5 \mathrm{~g} / \mathrm{L}$ magnesium sulfate, $0.5 \mathrm{~g} / \mathrm{L}$ potassium chloride, $0.01 \mathrm{~g} / \mathrm{L}$ ferrous sulfate, $30.0 \mathrm{~g} / \mathrm{L}$ sucrose and $1 \mathrm{~L}$ distilled water; initial pH 5.0). The flasks were incubated statically for 14 days in the dark (without shaking) at $28^{\circ} \mathrm{C}$ (Celestino et al., 2014) for secondary metabolite production.

\subsection{Secondary metabolite analysis}

The entire content of the Erlenmeyer $125 \mathrm{~mL}$ from fungal cultivation (containing fungal biomass and culture media) was mixed with ethyl acetate $(20 \mathrm{~mL})$ and shaken well in an orbital shaker (TECNAL. Model TE140, São Paulo, Brazil) $100 \mathrm{rpm}$ for $60 \mathrm{~min}$. The culture filtrate and solvent were taken in a separating funnel $(1: 1, \mathrm{v} / \mathrm{v})$ and mixed well and after separation, the solvent fraction was collected (Santos-Ebinuma, 2013). We repeated this procedure 20 times with 20 fresh cultivations resulting in $200 \mathrm{~mL}$ of the ethyl acetate phase got from $1000 \mathrm{~mL}$ of fungal cultivation. 
The ethyl acetate phase (72 mg) was concentrated in a rotary evaporator (IKA, RV10 digital, Santa Clara, CA, USA) and the subjected to Sephadex LH-20 column chromatography ( $\mathrm{h}=49 \mathrm{~cm}, \Phi=2.5 \mathrm{~cm}$ ) (Sigma-Aldrich, San Luis, Missouri, USA), eluted with methanol, and collected as 18 fractions. Fractions $4-10$ were subjected to silica gel column chromatography (70-230 mesh; h = 52 cm, $\Phi=2.5 \mathrm{~cm}$ ) eluted sequentially with hexane, hexane:ethyl acetate (10-55\% v/v), ethyl acetate:methanol (25-30\% v/v) and methanol and collected as 34 fractions. Fractions 27-29 were combined and subjected to microcrystalline cellulose column chromatography $(\mathrm{h}=20 \mathrm{~cm}, \Phi=3.5 \mathrm{~cm})$ (Merck) sequentially eluted with hexane, hexane:ethyl acetate (5-50\% v/v) and ethyl acetate, giving 34 fractions.

Fractions 27-29 were combined and subjected to microcrystalline cellulose column chromatography ( $\mathrm{h}=20 \mathrm{~cm}, \Phi=3.5 \mathrm{~cm}$ ) (Merck) eluted sequentially with hexane, hexane:ethyl acetate (5-50\% v/v) and ethyl acetate, giving 34 fractions. The combined fractions 27-29 were subjected to another chromatographic fractionation over silica gel (230-400 mesh; $\mathrm{h}=59 \mathrm{~cm}, \Phi=1,5 \mathrm{~cm})$, using dichloromethane:ethyl acetate $(9: 1 \mathrm{v} / \mathrm{v})$ as the eluent to yield the Compound 1 (Figure 1).

All decisions during the compound isolation were taken by analyzing the fractions of the chromatographic fractions

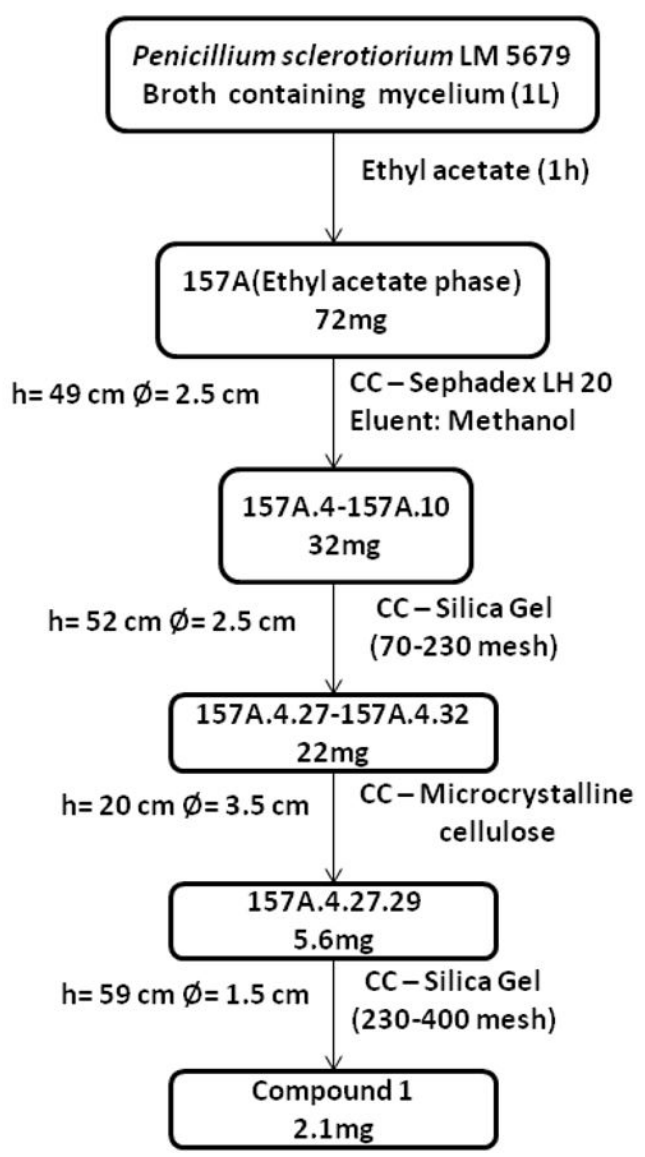

Figure 1. Chromatographic fractionation of the compound produced by Penicillium sclerotiorum LM 5679. by thin-layer chromatography (TLC) using ultraviolet light $(254 \mathrm{~nm} / 365 \mathrm{~nm})$ and the spray-reagent sulfuric vanillin aiming to isolate novel metabolites presenting a yellow colouration. The Figure 1 summarizes the chromatographic fractionation to reach the compound 1 .

The chemical structure of compound 1 was elucidated using Bruker Fourier 300 spectrometric by NMR ${ }^{1} \mathrm{H}$ (300 MHz) (see Figure 2), NMR ${ }^{13} \mathrm{C}(75 \mathrm{MHz}$ ) (see Figure 3), with the deuterated solvent Acetone-D6; Heteronuclear Single Quantum Coherence - HSQC and Heteronuclear Multiple Bond Correlation - HMBC (300/75 $150 \mathrm{MHz}$ ) experiments (see Figure 4 ). The chemical shifts $(\delta)$ were expressed in ppm and the coupling constants $(\mathrm{J})$ were in hertz $(\mathrm{Hz})$. High-resolution mass spectra were obtained on a MicroTOF-QII spectrometer (Bruker Daltonics, Billerica, Massachusetts, USA), which is an electrospray ionization (ESI) source. The maximum absorbance ( $\lambda \max$ ) was determined using a UV/VIS spectrophotometer (SP-1102, FEMTO 700 plus, São Paulo, Brazil) scanned at 400-700 nm.

\section{Results and Discussion}

\subsection{Identity of isolate LM 5679}

The isolation of fungi resulted in 200 fungal isolates, belonging to the genera: Penicillium (40\%), Aspergillus (32.5\%), Fusarium (11\%), Mucor (3\%), Trichoderma (2.5\%), Acremonium (1.5\%), Rhodotorula (1\%), Paecilomyces (1.5\%), Oidiondendron (1.5\%), Fonsecaeae (0.5\%), Gliocadium (0.5\%) and Mycelium sterilla (0.5\%).

The isolate, identified but the fungal collection as LM 5679 was investigated in detail as to its morphology and sequence of the ITS region of rDNA. We found green sporulating colonies on PDA after $7 \mathrm{~d}$ at $25^{\circ} \mathrm{C}$ that were $18-40 \mathrm{~mm}$ in diameter, with underside of the culture turning orange towards the centre, vivid orange. Microscopy revealed conidiophores monoverticillate with short to long necks, phialides ampulliform to cylindrical and conidia produced in columns, ellipsoidal, finely roughened. This morphology description is consistent with that of Penicillium species as described by Pitt and Hocking (2009). In order to identify the specie of LM 5679, the sequences of the Internal Transcribed Spacer (ITS) region from rDNA were analyzed and compared to those in the GenBank database and exhibited 99\% sequence similarity with the Accession EF488396.1 of Penicillium sclerotiorum. The ITS1-5,8s-ITS2 sequence of LM 5679 has now been desposited in NCBI-GeneBank database with accession number of MW058060.

\subsection{Secondary metabolite production}

The ethyl-acetate phase was selected for isolation and chemical characterization experiments. Purification procedures with different elution systems resulted in the isolation of a single compound (2.1 mg) (see Figure 1).

The ${ }^{1} \mathrm{H}$ NMR spectrum (Table 1 ) showed signals of three aromatic hydrogens with coupled meta $(\mathrm{J}=2.1 \mathrm{~Hz})$ at $\delta 6.18$ (H-2) and 6.20 (H-4, H-6). The hydrogens of methylene groups were verified in the region between $\delta 2.47-1.30$ and 


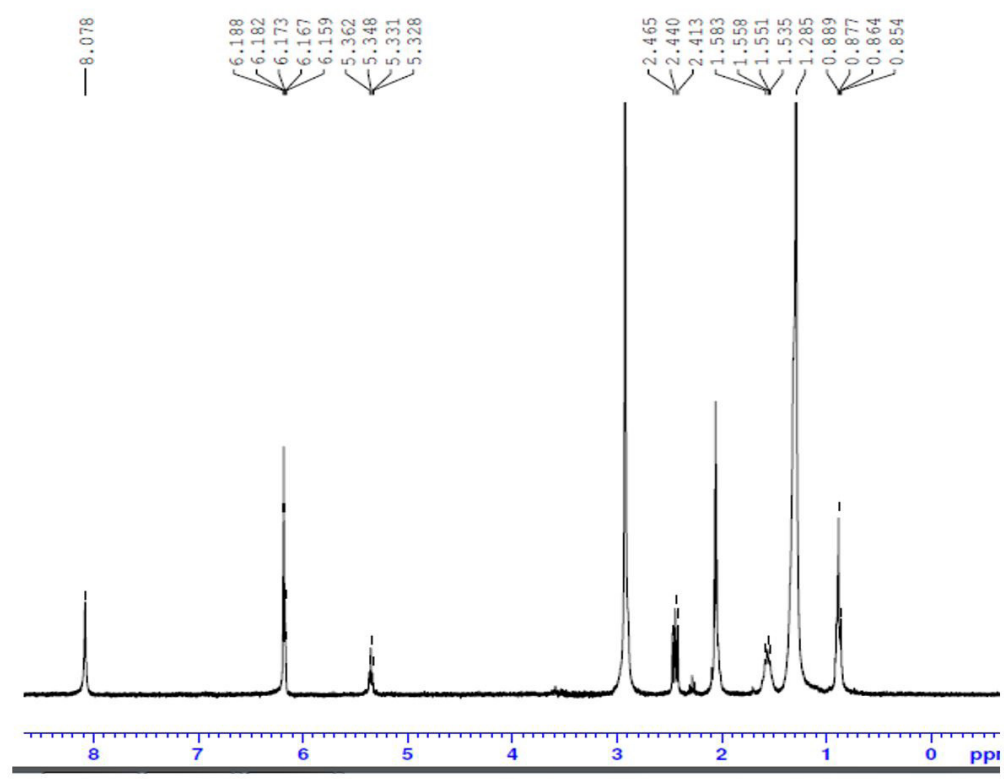

Figure 2. NMR ${ }^{1} \mathrm{H}(300 \mathrm{MHz}$ ) spectrum of the compound produced by Penicillium sclerotiorum LM 5679.

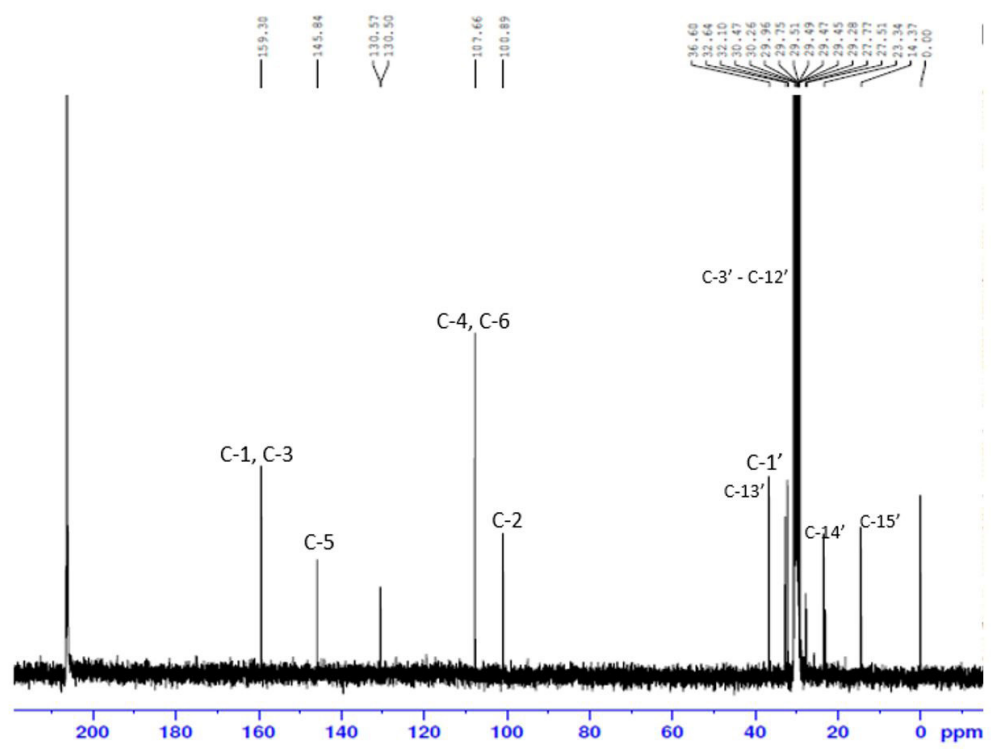

Figure 3. NMR ${ }^{13} \mathrm{C}(75 \mathrm{MHz})$ spectrum of the compound produced by Penicillium sclerotiorum LM 5679.

methyl group at $\delta 0.90$. The signal at $\delta 8.02$ was attributed to the hydrogen of hydroxyl group because it did not show correction with carbon in the HSQC experiment. ${ }^{13} \mathrm{C}$ NMR data associated with the DEPT allowed to identify olefinic carbons $\delta 100.89$ (C-2) and 107.66 with greater intensity corresponding to two carbons (C-4 and C-6). The chemical shifts of the aromatic ring were indicative of resorcinol (Barrero et al., 1989) and for the side chain methylenes between $\delta 36.59-23.33$ in addition to methyl at $\delta 14.30$ were verified. In the HMBC experiment (Table 1 ), the hydrogen at $\delta 2.47(\mathrm{H}-1$ ') showed corrections at J-3 with the carbons at 107.66 (C-4, C-6), and J-2 with 145.84 (C-5) and 32.10
(C-2 '). The high-resolution mass spectrum (negative ionization mode) showed the peak in $\mathrm{m} / \mathrm{z}$ to be 319.2631 [M-H], indicating a molecular formula of $\mathrm{C}_{21} \mathrm{H}_{36} \mathrm{O}_{2}$. Thus, this compound was identified as 5-pentadecyl resorcinol, an alkylresorcinol that is also known as adipostatin A or cardol (see Figure 5).

\subsection{Ecophysiology of 5-pentadecyl resorcinol}

The secondary metabolite 5-pentadecyl resorcinol is involved in trophic (and other organismal) interactions: it is cytotoxic, larvicidal, antimicrobial, has anticancer properties, and as an enzyme inhibitor (Zhu et al., 2011; 

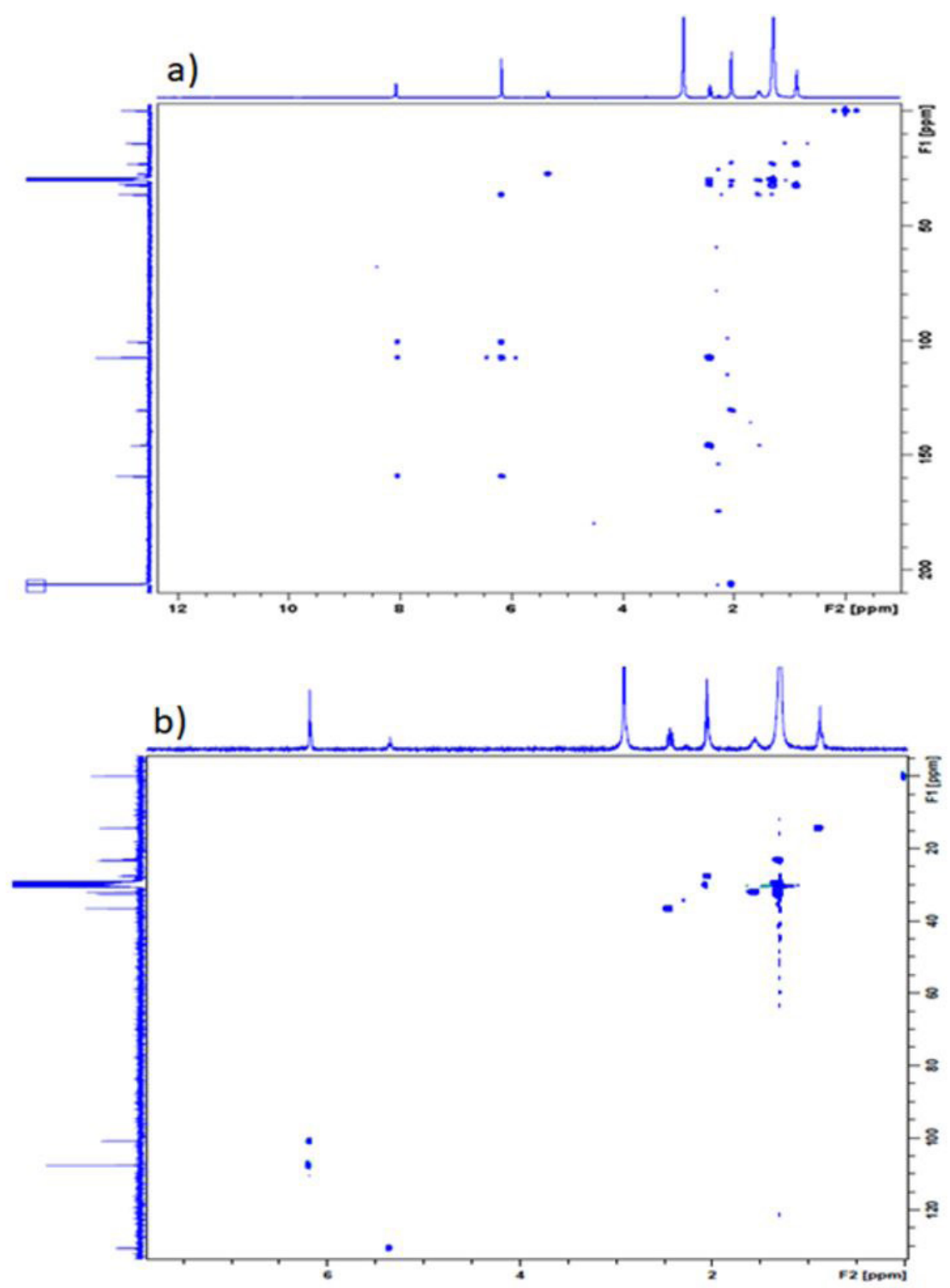

Figure 4. HMBC $150 \mathrm{MHz}$ (a) and HSQC $300 \mathrm{MHz}$ (b) spectrum of the compound produced by Penicillium sclerotiorum LM 5679.

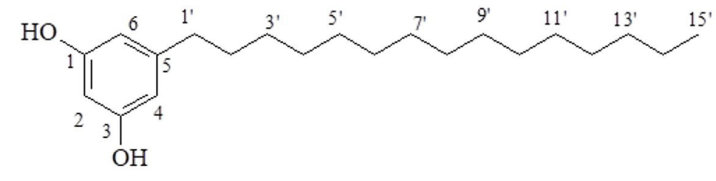

Figure 5. Chemical structure of the isolated substance (5-pentadecyl resorcinol) by Penicillium sclerotiorum LM 5679.

Liu et al., 2012; Gunenc et al., 2013; Murata et al., 2013; Zhou et al., 2016). It has commercial value as an intermediary compound for semi-synthesis chemistry. Plants, mosses, algae, sponges are known to produce this compound (Suaza-García and Coy-Barrera, 2014; Krishnapillai and Wijeratnam, 2017; Supriya et al., 2020), but only one other microbe (Table 2). Until now, P. sclerotiorum LM 5679 was not known to produce 5-pentadecyl resorcinol. Indeed, this compound has not been reported in any fungus except for a Fusarium (Table 2).

Alkylresorcinols are a group of secondary metabolites that belong to the phenol family and are also known as resorcinol lipids. These substances are comprised of an aromatic ring with hydroxyl groups at the 1- and 3-ring positions, an alkyl chain at the 5-position, and range between 1 and 29 carbon atoms in length (Żarnowski et al., $2002,2004)$. The characteristic structure of this group of compounds originates by condensation of acetyl-CoA subunits, which are synthesized by polyketide synthase enzymes type III (PKSs III) (Staunton and Weissman, 2001).

The specific metabolite 5-pentadecyl resorcinol acts as an inhibitor of glycerol-3-phosphate dehydrogenase. In fibroblast cells (3T3-L1), this substance can prevent the accumulation of triglycerides. In addition, alkylresorcinol is 
Table 1. NMR spectrum data of the compound produced by Penicillium sclerotiorum LM 5679.

\begin{tabular}{|c|c|c|c|c|c|}
\hline \multirow[b]{2}{*}{ № } & \multirow[b]{2}{*}{ NMR ${ }^{1} \mathbf{H}$} & \multirow[b]{2}{*}{ NMR ${ }^{13} C^{*}$} & NMR ${ }^{13} \mathrm{C}$ & \multirow[b]{2}{*}{ DEPT } & \multirow[b]{2}{*}{ НMBC } \\
\hline & & & $\begin{array}{l}\text { Barrero et al. } \\
\quad(1989)\end{array}$ & & \\
\hline 1 & --- & 159.29 & 156.29 & --- & \\
\hline 2 & $6.18 \mathrm{~d}(\mathrm{~J}=2.1 \mathrm{~Hz})$ & 100.89 & 100.38 & $\mathrm{CH}$ & 159.29 (C-1, C-3), 107.66 (C-4, C-6) \\
\hline 3 & --- & 159.29 & 156.29 & --- & \\
\hline 4 & $6.20 \mathrm{~d}(\mathrm{~J}=2.1 \mathrm{~Hz})$ & 107.66 & 108.12 & $\mathrm{CH}$ & 159.29 (C-3), 100.89 (C-2), 36.59 (C-1') \\
\hline 5 & --- & 145.84 & 146.9 & --- & \\
\hline 6 & $6.20 \mathrm{~d}(\mathrm{~J}=2.1 \mathrm{~Hz})$ & 107.66 & 108.12 & $\mathrm{CH}$ & $159.29(\mathrm{C}-1), 100.89$ (C-2), $36.59\left(\mathrm{C}-1^{\prime}\right)$ \\
\hline $1^{\prime}$ & $2.47 \mathrm{t}(\mathrm{J}=7.5 \mathrm{~Hz})$ & 36.59 & & $\mathrm{CH}_{2}$ & 145.84 (C-5), 107.66 (C-4, C-6), 32.10 (C-2') \\
\hline $2^{\prime}$ & $1.56 \mathrm{~m}$ & 32.10 & & $\mathrm{CH}_{2}$ & \\
\hline C-3'-C12' & $1.30-132 \mathrm{~m}$ & $30.46-30.06$ & & $\mathrm{CH}_{2}$ & \\
\hline $13^{\prime}$ & $1.30 \mathrm{~m}$ & 32.64 & & $\mathrm{CH}_{2}$ & \\
\hline $14^{\prime}$ & $1.30 \mathrm{~m}$ & 23.33 & & $\mathrm{CH}_{2}$ & 32.64 (C-13'), $14.37\left(\mathrm{C}-15^{\prime}\right)^{*}$ \\
\hline $15^{\prime}$ & $0.90 \mathrm{t}(\mathrm{J}=7,0 \mathrm{~Hz})$ & 14.30 & & $\mathrm{CH}_{3}$ & 32.10 (C-13'), 23.33 (C-14') \\
\hline $\mathrm{OH}$ & 8.02 & & & & 159.29 (C-1), 107.66 (C-4, C-6), 100.89 (C-2) \\
\hline
\end{tabular}

$\mathrm{d}=$ doubleto; $\mathrm{t}=$ tripleto; $\mathrm{m}=$ multipleto. ${ }^{*} \mathrm{HSQC}$.

Table 2. The reports that indicate that 5-pentadecyl resorcinol can be produced by microbial (rather than plant) systems .

\begin{tabular}{|c|c|c|c|}
\hline Type of microbe & Culture & Evidence of 5-pentadecyl resorcinol & Reference \\
\hline $\begin{array}{l}\text { Eukarya }^{\mathrm{b}} \text { : Fusarium } \\
\text { culmorum }\end{array}$ & $\begin{array}{l}\text { Potato broth with } \\
1 \%(\mathrm{w} / \mathrm{v}) \text { glucose at } \\
28^{\circ} \mathrm{C} \text {. }\end{array}$ & $\begin{array}{l}\text { Dry biomass }(8.6 \mathrm{~g}) \text { was extracted twice with } \\
\text { acetone. Supernatant was extracted twice with } \\
\text { ethyl acetate. 5-pentadecyl resorcinol was } \\
\text { detected by using preparative TLC silica gel } 60 \\
\text { plates, microcolorimetric method, GC and EI|MS. }\end{array}$ & Zarnowski et al. (2000) \\
\hline Penicillium sclerotiorum & $\begin{array}{l}\text { Defined nutrient } \\
\text { medium Czapek- } \\
\text { Dox broth }\end{array}$ & $\begin{array}{l}\text { The production of 5-pentadecyl resorcinol was } \\
\text { revealed using an ethyl acetate extraction which } \\
\text { yielded an orange pigment, and then confirmed } \\
\text { using NMR and mass spectrometry. }\end{array}$ & Current study \\
\hline \multicolumn{4}{|l|}{ Bacteria: none reported } \\
\hline Archaea: none reported & & & \\
\hline
\end{tabular}

aThere are many reports of 5-pentadecyl resorcinol production in diverse plant species (and even sponges); bonly reported thus far in fungi.

toxic to fibroblast tumor cells (KB) (Tanaka et al., 2011); has larvicidal activity against Aedes aegypti (Oliveira et al.2011); exhibits anticancer properties and inhibitory activity against lipourease (Kozubek et al., 2001); and is inhibitory to the ascomycetes Candida albicans and Saccharomyces cerevisiae (Yang et al., 2006).

There are about 100 research articles published about the antimicrobial compound 5-pentadecyl-resorcinol (some using the synonyms adispostatin A or cardol) according to Web-of-Science at October 2020. Surprisingly few of these focus on the mechanism-of-action of this antimicrobial. However, biochemical studies of cellular macromolecules indicate that 5-pentadecyl-resorcinol is inhibitory and/or structurally damaging to diverse macromolecular systems, including the plasma membranes and enzymes (Deszcz and Kozubek, 2000; Murata et al., 2013; Kustiawan et al., 2015; Masuoka et al., 2015). This substance is very hydrophobic, with a $\log \mathrm{P}_{\text {octanol-water }}$ of predicted to be in the range 7-8 (e.g. Kozubek, 1995). Previous studies have shown that compounds with $\log \mathrm{P}>1.95$ partition into the hydrophobic domains of the plasma membrane and proteins (Bhaganna et al., 2010). Hydrophobes thereby act as cellular stressors that entropically disorder biomacromolecules via a chaotropicity-mediated mechanism (Bhaganna et al., 2010; McCammick et al., 2010; Ball and Hallsworth, 2015). A considerable number of secondary metabolites, including those hydrophobes classed as volatile organic compounds, act as cellular stressors via this mechanism (Cray et al., 2013a, b, 2015; Suryawanshi et al., 2017).

Such compounds also induce oxidative stress in the cell, usually because they trigger lipid peroxidation. At very low concentrations, the 5-pentadecyl-resorcinol molecule (that has three double bonds) can act as an antioxidant according to in-vitro studies (Struski et al., 1990; Oliveira et al., 2011). However, this hydrophobe that has been shown to cause oxidative stress in vivo (Murata et al., 2013), and is highly inhibitory to microbial cells (Kubo et al., 2003; Murata et al., 2013; Zhou et al., 2016). Given the 
non-specific nature of hydrophobe-induced damage that is mediated by chaotropicity and oxidative stress (they can potentially affect all types of biomacromolecule and all types of cell), we believe that no forms of life are immune from adverse effects. The minimum inhibitory concentration of 5-pentadecyl-resorcinol for microbial systems is typically in the low mM range (Kubo et al., 2003), which is consistent with a mechanism-of-action as chaotropicity-mediated hydrophobic stressor (see Figure 1 of Cray et al., 2015).

It is intriguing to speculate how P. sclerotiorum can produce 5-pentadecyl-resorcinol without sustaining high levels of collateral damage. However, it is well-established that microbes that produce chaotropic substances in quantity have adaptations to stabilize their macromolecular systems that can include more-polar lipid headgroups, longer-chain and/or more-branched membrane lipids, highly efficient protein-stabilization proteins, and accumulation of polar (kosmotropic) substances that stabilize macromolecular systems (Hallsworth, 1998; Hallsworth et al., 2003; Bhaganna et al., 2010; Cray et al., 2015). More work is needed to establish whether P. sclerotiorum LM5679 also has these kinds of adaptation.

The current study demonstrates the incompleteness of our knowledge about the ecophysiology, and the biotechnological potential, of Amazonian soil fungi as secondary metabolite producers. Fungi, like all living systems, are constantly exposed to mechanistically diverse types of stress, from outside as well as those generated by the cell (Hallsworth, 2018). Alkylresorcinols can increase tolerance to stresses caused by oxidative damage (Agil et al., 2016) and high temperature (Deryabin et al., 2014), so it paradoxical that these substances are also highly toxic/ stressful/inhibitory in some species (Goebel et al., 2019; Li et al., 2020). More work is needed to determine the mechanisms at play that underlie this paradox. Further studies are also needed to understand commercial viability, and other ecophysiological roles, of 5-pentadecyl resorcinol in P. sclerotiorum.

\section{Acknowledgements}

The authors would like to recognize funding received from Fundação de Amparo à Pesquisa do Estado do Amazonas (FAPEAM - Universal Amazonas - EDITAL N.002/2018) and Coordenação de Aperfeiçoamento de Pessoal de Nível Superior (CAPES - Pró-Amazônia 2012, N.47). LAO would like to recognize funding received from Conselho Nacional de Desenvolvimento Científico e Tecnológico - CNPq (MSc bursary). PGH received a scholarship from Department of Agriculture, Environment and Rural Affairs (DAERA), Northern Ireland.

\section{References}

AGIL, R., PATTERSON, Z.R., MACKAY, H., ABIZAID, A. and HOSSEINIAN, F., 2016. Triticale bran alkylresorcinols enhance resistance to oxidative stress in mice fed a high-fat diet. Foods, vol. 5, no. 1, pp. 5. http://dx.doi.org/10.3390/foods5010005. PMid:28231100.
BALL, P. and HALLSWORTH, J.E., 2015. Water structure and chaotropicity: their uses, abuses and biological implications. Physical Chemistry Chemical Physics, vol. 17, no. 13, pp. 82978305. http://dx.doi.org/10.1039/C4CP04564E. PMid:25628033.

BARRERO, A.F., SANCHEZ, J.F., BARRÓN, A., CORRALES, F. and RODRIGUEZ, I., 1989. Resorcinol derivatives and other components of Ononis speciosa. Phytochemistry, vol. 28, no. 1, pp. 161-164. http://dx.doi.org/10.1016/0031-9422(89)85030-7.

BHAGANNA, P., VOLKERS, R.J., BELL, A.N., KLUGE, K., TIMSON, D.J., MCGRATH, J.W., RUIJSSENAARS, H.J. and HALLSWORTH, J.E., 2010. Hydrophobic substances induce water stress in microbial cells. Microbial Biotechnology, vol. 3, no. 6, pp. 701-716. http:// dx.doi.org/10.1111/j.1751-7915.2010.00203.x. PMid:21255365.

BITAS, V., KIM, H.S., BENNETT, J.W. and KANG, S., 2013. Sniffing on microbes: diverse roles of microbial volatile organic compounds in plant health. Molecular Plant-Microbe Interactions, vol. 26, no. 8, pp. 835-843. http://dx.doi.org/10.1094/MPMI-10-120249-CR. PMid:23581824.

CECI, A., PINZARI, F., RICCARDI, C., MAGGI, O., PIERRO, L., PETRANGELI PAPINI, M., GADD, G.M. and PERSIANI, A.M., 2018. Metabolic synergies in the biotransformation of organic and metallic toxic compounds by a saprotrophic soil fungus. Applied Microbiology and Biotechnology, vol. 102, no. 2, pp. 1019-1033. http://dx.doi. org/10.1007/s00253-017-8614-9. PMid:29138910.

CELESTINO, J.D.R., CARVALHO, L.E., LIMA, M.P., LIMA, A.M., OGUSKU, M.M. and SOUZA, J.V.B., 2014. Bioprospecting of Amazon soil fungi with the potential for pigment production. Process Biochemistry, vol. 49, no. 4, pp. 569-575. http://dx.doi. org/10.1016/j.procbio.2014.01.018.

CLARK, F., 1965. Methods of soil analysis. In: C. BLACK, ed. Actinomyces. Madison: American Society of Agronomy.

CRAY, J.A., BELL, A.N., BHAGANNA, P., MSWAKA, A.Y., TIMSON, D.J. and HALLSWORTH, J.E., 2013b. The biology of habitat dominance; can microbes behave as weeds? Microbial Biotechnology, vol. 6, no. 5, pp. 453-492. http://dx.doi.org/10.1111/1751-7915.12027. PMid:23336673.

CRAY, J.A., RUSSELL, J.T., TIMSON, D.J., SINGHAL, R.S. and HALLSWORTH, J.E., 2013a. A universal measure of chaotropicity and kosmotropicity. Environmental Microbiology, vol. 15, no. 1, pp. 287-296. http://dx.doi.org/10.1111/1462-2920.12018. PMid:23145833.

CRAY, J.A., STEVENSON, A., BALL, P., BANKAR, S.B., ELEUTHERIO, E.C., EZEJI, T.C., SINGHAL, R.S., THEVELEIN, J.M., TIMSON, D.J. and HALLSWORTH, J.E., 2015. Chaotropicity: a key factor in product tolerance of biofuel-producing microorganisms. Current Opinion in Biotechnology, vol. 33, pp. 228-259. http://dx.doi. org/10.1016/j.copbio.2015.02.010. PMid:25841213.

DERYABIN, D.G., GRYAZEVA, I.V., DAVYDOVA, O.K. and EL'-REGISTAN, G.I., 2014. Effect of alkylresorcinols on thermal denaturation and refolding of bacterial luciferase and synthesis of heat shock proteins revealed in the luminescent molecular and cellular test systems. Microbiology, vol. 83, no. 6, pp. 640-652. http:// dx.doi.org/10.1134/S0026261714060046. PMid:25941713.

DESZCZ, L. and KOZUBEK, A., 2000. Higher cardol homologs (5-alkylresorcinols) in rye seedlings. Biochimica et Biophysica Acta (BBA) -. Molecular and Cell Biology of Lipids, vol. 17, no. 2, pp. 241-250. http://dx.doi.org/10.1016/S1388-1981(99)00187-0.

FERRER, C., COLOM, F., FRASÉS, S., MULET, E., ABAD, J.L. and ALIÓ, J.L., 2001. Detection and identification of fungal pathogens by PCR and by ITS2 and 5.8S ribosomal DNA typing in ocular infections. Journal of Clinical Microbiology, vol. 39, no. 8, pp. 2873-2879. http://dx.doi.org/10.1128/JCM.39.8.2873-2879.2001. PMid:11474006. 
FLEMING, A., 1929. On the antibacterial action of cultures of a Penicillium, with special reference to their use in the isolation of B. influenzæ. British Journal of Experimental Pathology, vol. 10, no. 3, pp. 226-236. http://dx.doi.org/10.1590/S004296862001000800017.

GOEBEL, C., KOCK, M. and MERK, H., 2019. Toxicological risk assessment using the example of potential contact sensitization to resorcinol. Der Hautarzt, vol. 70, no. 12, pp. 948-952. http:// dx.doi.org/10.1007/s00105-019-04510-4. PMid:31754739.

GUNENC, A., HADINEZHAD, M., TAMBURIC-ILINCIC, L., MAYER, P.M. and HOSSEINIAN, F., 2013. Effects of region and cultivar on alkylresorcinols content and composition in wheat bran and their antioxidant activity. Journal of Cereal Science, vol. 57, no. 3, pp. 405-410. http://dx.doi.org/10.1016/j.jcs.2013.01.003.

HALLSWORTH, J.E., 1998. Ethanol-induced water stress in yeast. Journal of Fermentation and Bioengineering, vol. 85, no. 2, pp. 125-137. http://dx.doi.org/10.1016/S0922-338X(97)86756-6.

HALLSWORTH, J.E., 2018. Stress-free microbes lack vitality. Fungal Biology, vol. 122, no. 6, pp. 379-385. http://dx.doi.org/10.1016/j. funbio.2018.04.003. PMid:29801781.

HALLSWORTH, J.E., HEIM, S. and TIMMIS, K.N., 2003. Chaotropic solutes cause water stress in Pseudomonas putida. Environmental Microbiology, vol. 5, no. 12, pp. 1270-1280. http://dx.doi. org/10.1111/j.1462-2920.2003.00478.x. PMid:14641573.

HAO, X., ZHU, Y.G., NYBROE, O. and NICOLAISEN, M.H., 2020. The composition and phosphorus cycling potential of bacterial communities associated with hyphae of Penicillium in soil are strongly affected by soil origin. Frontiers in Microbiology, vol. 10, pp. 2951. http://dx.doi.org/10.3389/fmicb.2019.02951. PMid:31969866.

KOZLOVSKY, A.G., KOCHKINA, G.A., ZHELIFONOVA, V.P., ANTIPOVA, T.V., IVANUSHKINA, N.E. and OZERSKAYA, S.M., 2020. Secondary metabolites of the genus Penicillium from undisturbed and anthropogenically altered Antarctic habitats. Folia Microbiologica, vol. 65, no. 1, pp. 95-102. http://dx.doi.org/10.1007/s12223019-00708-0. PMid:30982204.

KOZUBEK, A., 1995. Determination of octanol/water partition coefficients for long- chain homologs of orcinol from cereal grains. Acta Biochimica Polonica, vol. 42, no. 2, pp. 247-251. http://dx.doi.org/10.18388/abp.1995_4617. PMid:8588472.

KOZUBEK, A., ARNOWSKI, R.Z., STASIUK, M. and GUBERNATOR, J. 2001. Natural amphiphilic phenols as bioactive compounds. Cellular E'Molecular Biology Letters, vol. 6, no. 2A, pp. 351-355.

KRISHNAPILLAI, N. and WIJERATNAM, R.S., 2017. Sap volatile components in relation to susceptibility of anthracnose and Aspergillus rot of mangoes (Mangifera indica L.). The Journal of Horticultural Science E'Biotechnology, vol. 92, no. 2, pp. 206-213. http://dx.doi.org/10.1080/14620316.2016.1249962.

KUBO, I., NIHEI, K. and TSUJIMOTO, K., 2003. Antibacterial action of anacardic acids against methicillin resistant Staphylococcus aureus (MRSA). Journal of Agricultural and Food Chemistry, vol. 51, no. 26, pp. 7624-7628. http://dx.doi.org/10.1021/jf034674f. PMid:14664518.

KUSTIAWAN, P.M., PHUWAPRAISIRISAN, P., PUTHONG, S., PALAGA, T., ARUNG, E.T. and CHANCHAO, C., 2015. Propolis from the stingless bee Trigona incisa from East Kalimantan, Indonesia, induces in vitro cytotoxicity and apoptosis in cancer cell lines. Asian Pacific Journal of Cancer Prevention, vol. 16, no. 15, pp. 6581-6589. http://dx.doi.org/10.7314/APJCP.2015.16.15.6581. PMid:26434878.

LI, Z.H., YANG, H.Y., ZHU, W.T., JING, D.D., LI, S.N. and YAN, P.K., 2020. Myrothecol A, a new alkylresorcinol with cytotoxicity from Myrothecium sp. Natural Product Research, vol. 0, no. 0, pp. 1-6. http://dx.doi.org/10.1080/14786419.2020.1762191. PMid:32380855.

LIU, L., WINTER, K.M., STEVENSON, L., MORRIS, C. and LEACH, D.N., 2012. Wheat bran lipophilic compounds with in vitro anticancer effects. Food Chemistry, vol. 130, no. 1, pp. 156-164. http://dx.doi.org/10.1016/j.foodchem.2011.07.023.

MASUOKA, N., NIHEI, K., MAETA, A., YAMAGIWA, Y. and KUBO, I., 2015. Inhibitory effects of cardols and related compounds on superoxide anion generation by xanthine oxidase. Food Chemistry, vol. 166, pp. 270-274. http://dx.doi.org/10.1016/j. foodchem.2014.06.021. PMid:25053055.

McCAMMICK, E.M., GOMASE, V.S., MCGENITY, T.J., TIMSON, D.J. and HALLSWORTH, J.E., 2010. Water-hydrophobic compound interactions with the microbial cell. In: K.N. TIMMIS, ed. Handbook of Hydrocarbon and Lipid Microbiology. Berlin: Springer, pp. 1451-1466. http://dx.doi.org/10.1007/978-3540-77587-4_99.

MURATA, W., TANAKA, T., KUBO, I. and FUJITA, K., 2013. Protective Effects of $\alpha$-tocopherol and ascorbic acid against cardolinduced cell death and reactive oxygen species generation in Staphylococcus aureus. Planta Medica, vol. 79, no. 9, pp. 768-774. http://dx.doi.org/10.1055/s-0032-1328555. PMid:23670625.

NOTARTE, K.I., YAGUCHI, T., SUGANUMA, K. and DELA CRUZ, T.E., 2018. Antibacterial, cytotoxic and trypanocidal activities of marine-derived fungi isolated from Philippine macroalgae and seagrasses. Acta Botanica Croatica, vol. 77, no. 2, pp. 141-151. http://dx.doi.org/10.2478/botcro-2018-0016.

OLIVEIRA, M.S.C., MORAIS, S.M., MAGALHÃES, D.V., BATISTA, W.P., VIEIRA, I.G., CRAVEIRO, A.A., DE MANEZES, J.E., CARVALHO, A.F. and DE LIMA, G.P., 2011. Antioxidant, larvicidal and antiacetylcholinesterase activities of cashew nut shell liquid constituents. Acta Tropica, vol. 117, no. 3, pp. 165-170. http:// dx.doi.org/10.1016/j.actatropica.2010.08.003. PMid:20707981.

PARK, M.S., OH, S.Y., FONG, J.J., HOUBRAKEN, J. and LIM, Y.W., 2019. The diversity and ecological roles of Penicillium in intertidal zones. Scientific Reports, vol. 9, no. 1, pp. 13540. http://dx.doi. org/10.1038/s41598-019-49966-5. PMid:31537866.

PITT, J.I. and HOCKING, A.D., 2009. Fungi and food spoilage. 3rd ed. New York: Springer, 524 p. http://dx.doi.org/10.1007/9780-387-92207-2.

RIDDELL, R.W., 1950. Permanent stained mycological preparations obtained by slide culture. Mycologia, vol. 42, no. 2, pp. 265-270. http://dx.doi.org/10.1080/00275514.1950.12017830.

SANTOS-EBINUMA, V.C., 2013. Produção e extração de colorantes naturais de Penicillium purpurogenum DPUA 1275+. São Paulo: Universidade de São Paulo, 199 p. Tese de Doutorado em Tecnologia de Fermentações.

STAUNTON, J. and WEISSMAN, K.J., 2001. Polyketide biosynthesis: a millennium review. Natural Product Reports, vol. 4, no. 4, pp. 380-416. http://dx.doi.org/10.1039/a909079g.

STRUSKI, D.G.J., KOZUBEK, A. and NATURFORSCH, Z., 1990. Cereal grain alk(en)ylresorcinols protect lipids against ferrous ioninduced peroxidation. Journal of Biosciences, vol. 47, pp. 47-50. http://dx.doi.org/10.18388/abp.1995_4589.

SUAZA-GARCÍA, E.R. and COY-BARRERA, E., 2014. Alquilresorcinoles: compuestos naturales con importancia biológica. Revista Facultad de Ciencias Básicas, vol. 10, no. 2, pp. 210-222. http:// dx.doi.org/10.18359/rfcb.332.

SUPRIYA, A., KUMAR, A. and KUDACHIKAR, V.B., 2020. A comparison investigation on antioxidant activities, constitutive antifungal phenolic lipids and phenolics contents of anthracnose resistant and susceptible mango fruit cultivars. International Journal of 
Fruit Science, vol. 20, no. 4, pp. 692-704. http://dx.doi.org/10. 1080/15538362.2019.1668332.

SURYAWANSHI, R.K., PATIL, C.D., KOLI, S.H., HALLSWORTH, J.E. and PATIL, S.V., 2017. Antimicrobial activity of prodigiosin is attributable to plasma-membrane damage. Natural Product Research, vol. 31, no. 5, pp. 572-577. http://dx.doi.org/10.1080 /14786419.2016.1195380. PMid:27353356.

TANAKA, A., ARAI, Y., KIM, S.N., HAM, J. and USUKI, T., 2011. Synthesis and biological evaluation of bilobol and adipostatin A. Journal of Asian Natural Products Research, vol. 13, no. 4, pp. 290-296. http://dx.doi.org/10.1080/10286020.2011.55482 8. PMid:21462031.

TOJU, H. and SATO, H., 2018. Root-associated fungi shared between arbuscular mycorrhizal and ectomycorrhizal conifers in a temperate forest. Frontiers in Microbiology, vol. 9, pp. 433. http://dx.doi.org/10.3389/fmicb.2018.00433. PMid:29593682.

WANG, C.Y., HAO, J.-D., NING, X.-Y., WU, J.-S., ZHAO, D.-L., KONG, C.-J., SHAO, C.-L. and WANG, C.-Y., 2018. Penicilazaphilones D and $\mathrm{E}$ : two new azaphilones from a sponge-derived strain of the fungus: Penicillium sclerotiorum. RSC Advances, vol. 8, no. 8, pp. 4348-4353. http://dx.doi.org/10.1039/C7RA13327H.

WHITE, T.J., BRUNS, T., LEE, S. and TAYLOR, J.W., 1990. Amplification and direct sequencing of fungal ribosomal RNA genes for phylogenetics. In: M.A. INNIS, D.H. GELFAND, J.J. SNINSKY and T.J. WHITE, eds. PCR protocols: a guide to methods and applications. St. Louis: Academic Press, pp. 315-322.

XIN, Q., PAN, T., ZHANG, W.-M. and WANG, Z., 2019. Submerged culture of marine-derived Penicillium sclerotiorum FS50 to produce sclerotiorin. Process Biochemistry, vol. 79, pp. 28-31. http://dx.doi.org/10.1016/j.procbio.2018.12.009.
YANG, S.W., CHAN, T.M., TERRACCIANO, J., LOEBENBERG, D., PATEL, M., GULLO, V. and CHU, M., 2006. A new 5-alkenylresorcinol sch 725681 from Aspergillus sp. ChemInform, vol. 59, no. 3, pp. 725681. http://dx.doi.org/10.1002/chin.200639223. PMid:16724460.

ZARNOWSKI, R., LEWICKA, T. and PIETR, S.J., 2000. Production and secreation of $5-\mathrm{w}$-alkyl resorcinols by Fusarium culmorum. Zeitschrift für Naturforschung C, vol. 55, no. 9-10, pp. 846-848. http://dx.doi.org/10.1515/znc-2000-9-1030. PMid:11098843.

ŻARNOWSKI, R., SUZUKI, Y., YAMAGUCHI, I. and PIETR, S.J., 2002. Alkylresorcinols in barley (Hordeum vulgare L. distichon) grains. Zeitschrift für Naturforschung C, vol. 57, no. 1-2, pp. 57-62. http:// dx.doi.org/10.1515/znc-2002-1-210. PMid:11926544.

ŻARNOWSKI, R., SUZUKI, Y., ZARNOWSKA, E.D., ESUMI, Y., KOZUBEK, A. and PIETRA, S.J., 2004. 5-n-alkylresorcinols from the nitrogenfixing soil bacterium Azotobacter chroococcum Az12. Zeitschrift für Naturforschung C, vol. 59, no. 5-6, pp. 318-320. http://dx.doi. org/10.1515/znc-2004-5-604. PMid:18998393.

ZHOU, S., WANG, M., ZHAO, H.G., HUANG, Y.H., LIN, Y.Y., TAN, G.H. and CHEN, S.L., 2016. Penicilazaphilone C, a new antineoplastic and antibacterial azaphilone from the marine fungus Penicillium sclerotiorum. Archives of Pharmacal Research, vol. 39, no. 12, pp. 1621-1627. http://dx.doi.org/10.1007/s12272-016-0828-3. PMid:27605109.

ZHU, Y., CONKLIN, D.R., CHEN, H., WANG, L. and SANG, S., 2011. 5 -alk(en)ylresorcinols as the major active components in wheat bran inhibit human colon cancer cell growth. Bioorganic E' Medicinal Chemistry, vol. 19, no. 13, pp. 3973-3982. http:// dx.doi.org/10.1016/j.bmc.2011.05.025. PMid:21658963. 